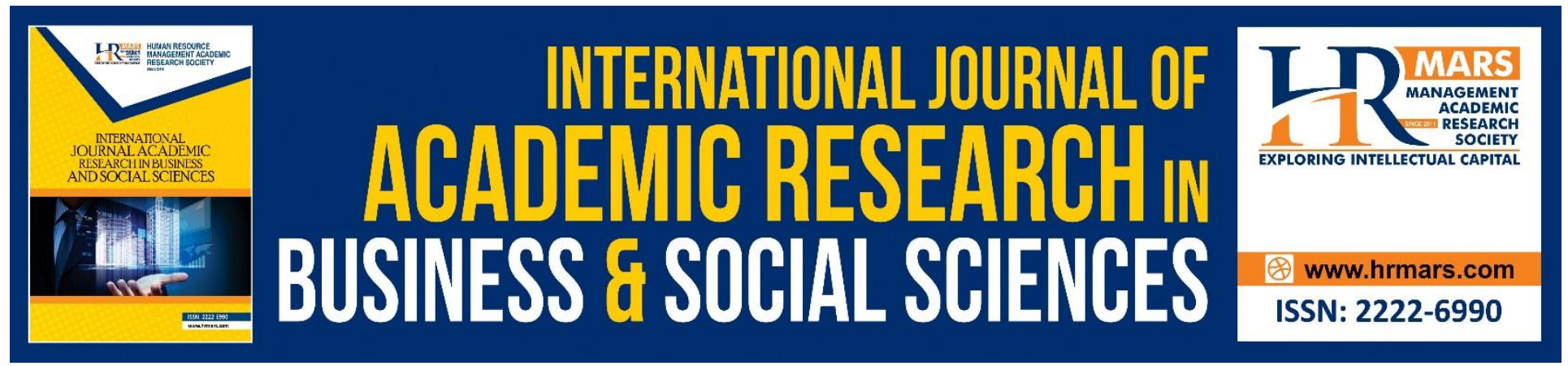

\title{
Linking Human Resource Management Practices and Employee Performance through Networking Behavior: A Perspective from Malaysian Private University
}

Ahmad Farid Amin and Nik Hasnaa Nik Mahmood

To Link this Article: http://dx.doi.org/10.6007/IJARBSS/v10-i7/7432

DOI:10.6007/IJARBSS/v10-i7/7432

Received: 05 April 2020, Revised: 09 May 2020, Accepted: 18 June 2020

Published Online: 29 July 2020

In-Text Citation: (Amin, 2020)

To Cite this Article: Amin, A. F. N. H. N. M. (2020). Linking Human Resource Management Practices and Employee Performance through Networking Behavior: A Perspective from Malaysian Private University. International Journal of Academic Research in Business and Social Sciences, 10(7), 413-431.

Copyright: @ 2020 The Author(s)

Published by Human Resource Management Academic Research Society (www.hrmars.com)

This article is published under the Creative Commons Attribution (CC BY 4.0) license. Anyone may reproduce, distribute, translate and create derivative works of this article (for both commercial and non-commercial purposes), subject to full attribution to the original publication and authors. The full terms of this license may be seen

at: http://creativecommons.org/licences/by/4.0/legalcode

Vol. 10, No. 7, 2020, Pg. 413 - 431

http://hrmars.com/index.php/pages/detail/IJARBSS

JOURNAL HOMEPAGE

Full Terms \& Conditions of access and use can be found at http://hrmars.com/index.php/pages/detail/publication-ethics 


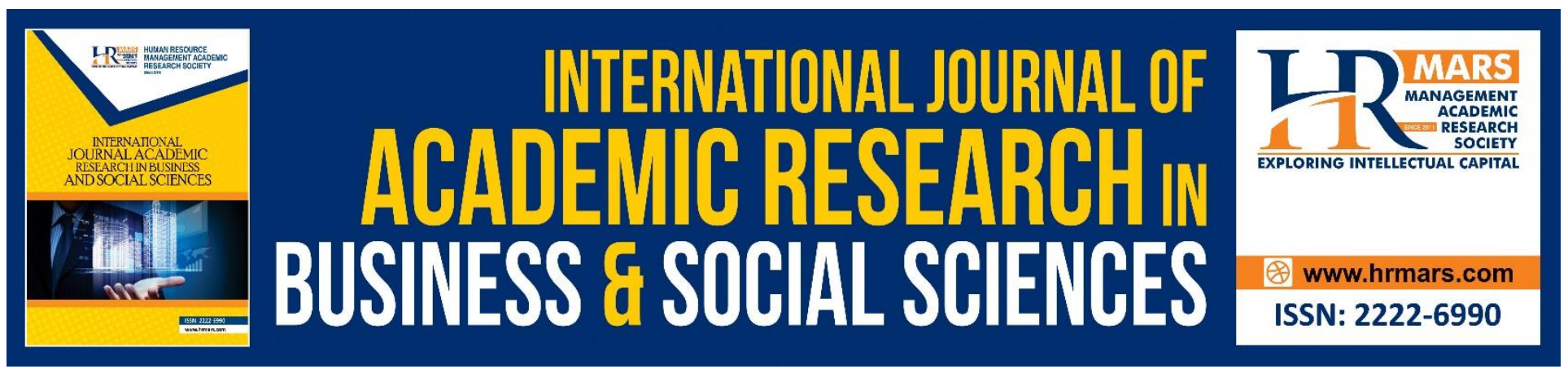

\title{
Linking Human Resource Management Practices and Employee Performance through Networking Behavior: A Perspective from Malaysian Private University
}

\author{
Ahmad Farid Amin and Nik Hasnaa Nik Mahmood \\ Razak Faculty of Technology and Informatics, Universiti Teknologi Malaysia (UTM) Kuala Lumpur, \\ Level 7, Razak Tower, Jalan Sultan Yahya Petra, 54100 Kuala Lumpur, Malaysia \\ Email: ahmadfaridamin@gmail.com
}

\begin{abstract}
This paper aims to explore the relationship between human resource management practices and employee performance in Malaysian private university. This paper proposed networking behavior as mediator between HRM-employee performance linkages. To develop this conceptual model, the paper reviews previous literature on HRM, networking behavior and employee performance. This paper proposes a theoretical model of HRM-employee performance linkage with networking behavior as mediator that will better explain the relationships. It argues that HRM practices namely as recruitment and selection practices, and compensation and benefits practices may influence employee's networking behavior and their performance. At the same time, networking behavior would also affect employee performance. Each of these variables is explored and looking for possibility on the role of networking behavior as mediator. Two hundred and forty-two usable questionnaires are collected to empirically test the hypothesis using IBM SPSS Statistics 23 software and Smart Partial Least Square (SmartPLS) version 3. This paper concludes that recruitment and selection practices, and networking behaviour have significant relationship towards employee performance. Furthermore, networking behavior did not mediate the relationships between recruitment and selection practices, and compensation and benefits practices on employee performance. Therefore, these results should assist organization in providing insight towards managing employees of Malaysian private universities.
\end{abstract}

Keywords: Recruitment and Selection Practices, Compensation and Benefits Practices, Employee Performance, Networking Behavior, Malaysian Private University.

Introduction

In today's dynamic and continuous changing world, employees are an important intangible asset for any organization as they are the greatest determinant to the organization success. In developing countries such as Malaysia for instance, employees are experiencing poor performance in private universities (Basu, Jeyasingam, Habib, Letchmana, \& Ravindran, 2017). A study by Ghasemy et al. 
(2018) on investigating issues in Malaysian private institutions, found that the staff have difficulty in achieving their key performance index (KPI) as only minimal amount of hours development program implemented to them. Ghasemy et al. (2018) have also argued the behaviour of the employees their challenge on collaboration and cooperation as these component are important among top six priorities in Malaysian higher education which are achieving goals, KPIs (Key Performance Indicators) and standards, teaching and delivering programs, research, publications and finance and grants.

Furthermore, education sector is important to Malaysia as its contribution to the Gross Domestic Product (GDP) and to large job opportunities especially in private higher institutions (Basu et al., 2017). Since education is one of the sectors with high potential to contribute toward Malaysia's economy, it is important to investigate the determinants that will improve their employee performance which later contribute to their university performance. Furthermore, Malaysian higher education institutions have been subjected to considerable reforms as highlighted by the Ministry of Higher Education, Dr. Maszlee Malik in his speech (Malik, 2019). Therefore, universities today need management practices that will help them increase their effectiveness and efficiency and become more competitive.

A large and growing body of literature in the past has investigated human resource management (HRM) to improve employee performance. HRM is essentially about matching human resources to the organization's strategic and operational needs and ensuring the full utilization of the employees (Jiang, Takeuchi, \& Lepak, 2013). Most of the studies in investigating the HRM effect towards employee performance focused in manufacturing industry (Ikem, 2019), hospitality (Aboyassin \& Sultan, 2017), health care (Gile, 2013), retail industry (Imna \& Hassan, 2015) but studies on education industry are limited especially in private university (Amin, Khairuzzaman Wan Ismail, Zaleha Abdul Rasid, \& Daverson Andrew Selemani, 2014). Networking is another strategy implemented by organization to improve the work performance of employees (Tauhed, Roziah Mohd. Rasdi, Rahinah Ibrahim, \& Bahaman Abu Samah, 2019; Nesheim, Olsen, \& Sandvik, 2017; Yen, Chen, \& Su, 2020). Private organizations have encouraged their employees to network in exploring ideas and information sharing to improve their employee performance (Moqbel \& Aftab, 2015; Ravi, 2019). Another studies by Rasdi, Garavan, \& Ismail, (2013), resulted that networking may improve the performance of the employees in higher education institution.

While networking behavior of management staff seems important in higher education to improve their performance, this paper will also highlight the possible intervene mediating variables of networking behavior in relationship between human resource management and employee performance. The theoretical argument in this study states that employees are guided by the HRM practices and policies may shape the networking behavior of management team. As a result, networking behavior of employee will be strengthened since the HRM practices are designed to align employees' attitude and behavior with organizational values and strategic goals. Organization performance is thus, improved with the strengthened managerial networking of employees. Therefore, the proposition of this study is that networking behaviour may act as mediator over the effects of HRM on employee performance. This study also attempts to use and merge the abilitymotivation-opportunity (AMO) theory and social capital theory to explain the relationship between HRM, networking behavior and employee performance in Malaysian context.

This study is very important in contributing its significance. First, this study is contributed to the existing literature by investigating the role of networking behaviour in mediating the HRMemployee performance linkages. Second, the organization top management may have to encourage 
INTERNATIONAL JOURNAL OF ACADEMIC RESEARCH IN BUSINESS AND SOCIAL SCIENCES

Vol. 10, No. 7, July, 2020, E-ISSN: 2222-6990 @ 2020 HRMARS

their employees to build their own network as networking also vital for employees in private higher education for them to improve their university performance for instance inter-university collaboration and partnership with industries.

\section{Research Question}

Based on the literature reviewed above, the main issues can be addressed in this paper are:

$\mathrm{R} 1$ : What is the relationship between human resource management practices and employee performance?

R2: What is the relationship between networking behavior and employee performance?

R3: Can networking behavior mediate the relationship between human resource management practices and employee performance?

\section{Research Objectives}

From the problem that has been discussed above, the objectives of this paper are:

- To examine the relationship between human resource management practices and employee performance.

- To examine the relationship between networking behavior and employee performance.

- To examine whether networking behavior mediate the relationship between human resource management practices and employee performance.

\section{Literature Review and Hypothesis Development}

The term human resource management (HRM) is used by (Jackson, Schuler, \& Jiang, 2014) to refer HRM as an organizational management activity group of practices that used to manage their employees. For Armstrong (2006), HRM means strategic and integrated management approach towards their employees which collectively supporting their organization objective. In 2002, Guest in his study reported that the performance of organization solely depending on their employees. In case their employees are not performing well, it will affect their organization performance too.

In recent studies by Amin et al, there have been an identified HRM into several practices such as career planning, job definition, employee participation, selection and recruitment, compensation and benefits, performance appraisals, employee participation, and training and development. These practices have been identified to improve employees and organization performance. On other hand, Jiang et al., (2012) in his analysis identifies HRM into selection system, training, job definition, performance appraisal system, compensation system, career planning system and employee participation. The following HRM practices are therefore considered for the purpose of this study: selection and recruitment, training and development, performance appraisal and, compensation and benefits.

The previous research on the function of human resource management practices has been rooted on organizational performance while employees should be the focus in term of development and performance. For instance, recruitment and selection practices is the foremost function in human resource management practices. The quality of employee recruited by the university is depends on how efficient the recruitment and selection are conducted (Nasir, 2017). Jolaosho et al., (2018) examines the effect of recruitment and selection practices towards employee performance in Nigeria. By using simple random sampling technique, 50 members of customer service center were 
selected to take part in this study. The result showed that recruitment and selection practices have positive impact towards the organisation through their employee's performance. The researcher also concluded that recruitment and selection practices should be prioritized by the organisation and should be included in their key performance index (KPI).

Meanwhile, study by Baba \& David (2020) on the relationship between HR practices and employee performance found that compensation and benefits practices have significant effect on the work performance of the employees. This study was conducted in multi-national companies (MNCs) at Ghana. Another study by Rashid, Hamza, \& Said, (2018) in investigating the impacts of rewards on employees has also produced the positive outcome. The study which was conducted among academic staff in Malaysian universities found that rewards has significant relationship on their work performance.

Previous studies on the relationship between HRM and employee's performance have used human capital theory as underlining the relationship between the variables (Chang \& Chen, 2011; (Lin et al., 2017)). However, there is lack of literature on the usage of ability-motivation-opportunity (AMO) theory even Juan A. Marin-Garcia \& Juan Martinez Tomas (2016) has considered the theory as excellent model to improve employee importance. This study employed the theory of AMO as underlining justification on the relationship between HRM practices and employee performance.This review formulated the hypothesis that human resource management practices, namely recruitment and selection, training and development, rewards and benefits, and performance appraisals will have positive relationship toward employee performance. Therefore, the study hypothesized that:

$\mathrm{H} 1$ : Recruitment and selection practices have positive relationship on employee performance.

$\mathrm{H} 2$ : Compensation and benefits practices have positive relationship on employee performance.

It is necessary here to clarify exactly what is meant by networking. The definition of networking behavior by Orpen (1996) is process of building up and maintaining a set of informal cooperative relationships with individuals other than the manager's direct reports. This is because the immediate manager in the expectation that such relationships will enable the manager to develop and perform more effectively or to achieve more objective and subjective career success. Another definition by Forret \& Dougherty (2001) is an individual who attempts to develop and maintain relationships with others who have the potential to assist them in their work or career. While a variety of definitions of the term networking behavior have been suggested, this paper will use the definition suggested by Y. McCallum, L. Forret, \& Wolff (2014) who saw it as developing, building and maintaining relationship with internal and external contacts in aiding assistance towards knowledge sharing on work related matters.

There is a large volume of published studies describing the role of networking behavior on career developments and job promotion (Porter, Woo, \& Campion, 2016), enhancing internal visibility (Forret \& Dougherty, 2004), establishment of business (Sharafizad, 2012). However, research on networking as a strategy to improve employee performance is scarce. Research conducted by $Y$. McCallum et al., (2014) on networking behavior found that networking positively related to employee performance (Ravi, 2019; Wu, Liu, \& Shang, 2018; Marqués-Sánchez et al., 2018). This review formulated the hypothesis that networking will have positive relationship toward employee performance.

H3: Networking behavior have positive relationship on employee performance

This paper attempts to combine AMO theory with social capital theory to maximize the performance outcomes of the employees as recommended by Nor \& Abdullah (2020) andAlbrecht, Bakker, 
Gruman, Macey, \& Saks (2015). Besides that, Chang \& Chen (2011) and Liu, Hui, Lee, \& Chen, (2013) points out that the linkages of HRM-employee performance have been investigated in centuries but there is possibility to have intervene variables to better explain the relationship. This view is supported by Garg \& Sharma (2015) who investigates the role of employee engagement as mediator between HRM practices and employee performance. The outcome of the study shown significant role of employee engagement as mediator towards HRM-employee linkages.

Elsewhere, Gibson et al., (2014) and Spurk, Kauffeld, Barthauer, \& Heinemann, (2015) highlighted that networking is influenced by a variety of individual, employee and organizational level. Recent study by Amin et al 2014 suggested that the most initiative taken in Malaysian universities to empower their employees are professional development training and continuous improvement, staff affairs management and encouragement on communication among staff through discussion and dialogue.

The theoretical argument is this study states that employees are driven by human resource management to their networking behavior, and thus will improve their performance. This study attempts to use ability-motivation-opportunity (AMO) theory, and social capital theory to explain the relationship between HRM, networking behavior and employee performance in Malaysian private university.

Wright, Dunford, \& Snell (2001) argued that human resource practices lead to higher performance through their effects on employee-based firm capabilities and resources. We have argued that strategic human resources management can be used to manage managerial networks of top management team, and managerial networking derived organization performance. Therefore, we expect that one-way HRM affect employee performance is through their effect on managerial networking among top management team. Furthermore, Hernandez-Espallardo, Osorio-Tinoco, \& Rodriguez-Orejuela (2018) in his empirical research on organizational performance also found that inter-organizational collaboration can mediate the relationship of human resource management and firm's performance. By using structural equation model, the hypothesis was tested and analyzed from data collected through surveys among sample of Colombian manufactures. Another research conducted by Subramony, Segers, Chadwick, \& Shyamsunder (2018) also found evidence that social capital mediates the human resource management and their performance. By utilizing a sample of 223 organization in a growing economy in India, they found that social capital fully mediates the relationship of the variables measured.

The researcher believe that networking activity can interfere with the practice of human resource management and employee performance by incorporating social capital theory and AMO theory. Therefore, the study hypothesized that:

$\mathrm{H} 4$ : Networking behavior can mediate the relationship between recruitment and selection practices and employee performance.

H5: Networking behavior can mediate the relationship between compensation and benefits practices, and employee performance.

Based on the literature discussed above, this study proposed human resource management are strongly affecting employee's performance through their networking behavior. In addition, networking behavior has proven to influence performance of employees. 
INTERNATIONAL JOURNAL OF ACADEMIC RESEARCH IN BUSINESS AND SOCIAL SCIENCES Vol. 10, No. 7, July, 2020, E-ISSN: 2222-6990 @ 2020 HRMARS

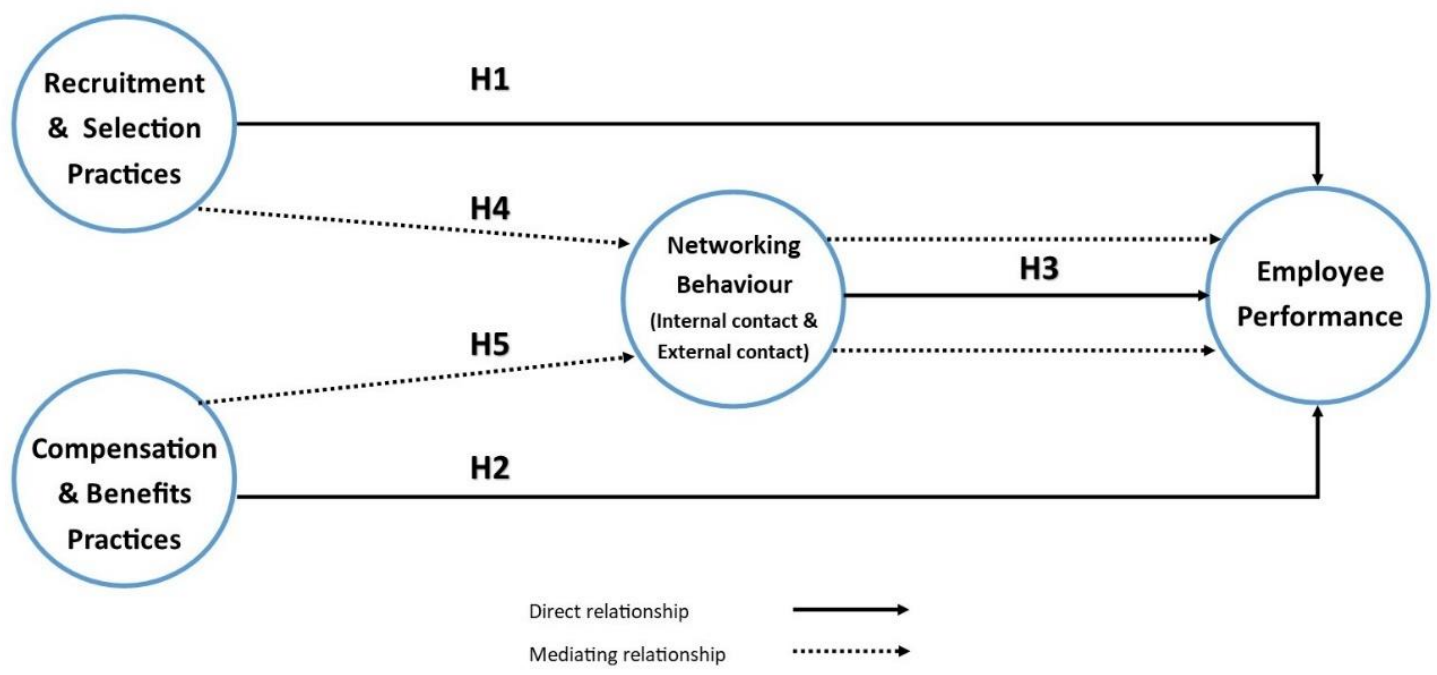

Figure 1: Conceptual Framework of networking behavior as mediator between recruitment and selection practices, compensation and benefits practices, performance appraisal practices and employee job performance

\section{Research Methodology}

This study will use quantitative methods to examine the relationship between variables (human resource management, networking behavior and job performance). Quantitative approach provides valid and reliable statistical evidence of relationship strength and guidance (Amaratunga, Baldry, Sarshar, \& Newton, 2002). As stressed by (Punch, 2003) that the choice of conducting research should align with the research problem and objectives therefore quantitative approach is used to answer the research questions and test the hypothesis formulated in previous section.

The researcher has developed a set of questionnaires as research instrument to collect the data among management staff at the private university in Malaysia. The management staff participated are Executive, Assistant Managers, Managers, Deputy Dean, Head of Section and Dean. There are three section for the questionnaires. The indicators for human resource management practices which comprises of recruitment and selection practices, and compensation and benefits practices are adopted from originally Loo \& Beh (2015). The indicators for networking behaviors are adopted from (Wolff, Schneider-Rahm, \& Forret (2011) which comprises of internal contact and external contact. The last indicators are employee job performance which adopted from Williams \& Anderson (1991). The measured indicators for every construct were based on Five-point Likert scale. Pre-test and pilot test were conducted to ensure the validity and reliability of the instrument. From a total of 300 sets of questionnaires distributed, 250 sets were safely received and only 242 are usable to be used. The data then been recorded in IBM SPSS version 23 and analyzed using SmartPLS version 3. The statistical calculation and model measurement were performed, and the results of findings are interpreted in the next section.

\section{Data Analysis and Results}

From the total of 242 questionnaire distributed, female respondents contributed to $53.7 \%$ and it is slightly more than male respondents (46.3\%). Majority of the respondents are degree holder (40.1\%), and age between range 31-40 years old (45.5\%). Most of them also have working experience between 5-10 years in the university, and $52.1 \%$ respondents are among executive level. 
INTERNATIONAL JOURNAL OF ACADEMIC RESEARCH IN BUSINESS AND SOCIAL SCIENCES Vol. 10, No. 7, July, 2020, E-ISSN: 2222-6990 @ 2020 HRMARS

In the first stage of analysis, reliability and validity of the model will be assessed based on internal consistency reliability, convergent validity and discriminant validity. The results as in Table 1 below. Internal consistency reliability measures the extent to which items are measures of a construct (Hair Jr, Sarstedt, Ringle, \& Gudergan, 2017). Internal consistency reliability holds true when Composite Reliability (CR) of each construct is greater that threshold value of 0.7 (Hair Jr, Hult, Ringle, \& Sarstedt, 2016). Composite reliability is a more precise measure as compared to Cronbach alpha for assessing internal consistency reliability (Bagozzi \& Yi, 1988). Table 2.0 shows that CR value for each construct in the model ranges from 0.873 to 0.938 and this is above the recommended cut off value of 0.7 . Hence, results showed that indicators measuring a construct have satisfactory internal consistency reliability.

Convergent validity measures that indicators of a construct highly correlate with each other than with indicators of any other construct (Hair Jr et al., 2017). It is assessed by examining outer loadings, Average Variance Extracted (AVE) and Composite Reliability (CR) value. As a rule of thumb for acceptable convergent validity, Chin (1997) recommended outer loadings should be greater than 0.6 and AVE should be above threshold of 0.5 (Hair Jr et al., 2016; Nunnally, 1978). Furthermore, Hair Jr et al., 2016) suggested to retain weak factor loadings (such as 0.4 to 0.7 ) if other indicators loadings are high and can explain $50 \%$ variance. However, the indicator with outer loadings below 0.4 must be dropped. Table 4.6 exhibits that all indicators loadings are above the threshold value of 0.6 and AVE values for all indicators are above 0.5 . Thus, indicators of the constructs have satisfactory convergent validity.

TABLE 1: Evaluation of Measurement Model

\begin{tabular}{|l|c|c|c|c|c|}
\hline \multicolumn{1}{|c|}{ Construct } & Indicators & Loadings $^{\mathbf{a}}$ & AVE $^{\mathbf{b}}$ & CR $^{\mathbf{c}}$ & Rho_A $^{\mathbf{d}}$ \\
\hline $\begin{array}{l}\text { Recruitment \& Selection } \\
\text { Practices }\end{array}$ & RS1 & 0.705 & 0.599 & 0.882 & 0.843 \\
\hline & RS2 & 0.746 & & & \\
\hline & RS3 & 0.792 & & & \\
\hline & RS4 & 0.759 & & & \\
\hline & RS5 & 0.862 & & & \\
\hline $\begin{array}{l}\text { Compensation \& Benefits } \\
\text { Practices }\end{array}$ & CB1 & 0.800 & 0.650 & 0.903 & 0.882 \\
\hline & CB2 & 0.811 & & & \\
\hline & CB3 & 0.833 & & & \\
\hline & CB4 & 0.810 & & & \\
\hline & CB5 & 0.779 & & & \\
\hline Internal Contact Networking & IC1 & 0.733 & 0.536 & 0.873 & 0.832 \\
\hline Behaviour & IC2 & 0.823 & & & \\
\hline & IC3 & 0.698 & & & \\
\hline & IC4 & 0.641 & & & \\
\hline & IC5 & 0.744 & & & \\
\hline & IC6 & 0.742 & & & \\
\hline External Contact Networking & EC1 & 0.649 & 0.508 & 0.892 & 0.862 \\
\hline Behavior & EC2 & 0.740 & & & \\
\hline & EC3 & 0.747 & & & \\
\hline
\end{tabular}


INTERNATIONAL JOURNAL OF ACADEMIC RESEARCH IN BUSINESS AND SOCIAL SCIENCES Vol. 10, No. 7, July, 2020, E-ISSN: 2222-6990 @ 2020 HRMARS

\begin{tabular}{|l|l|l|l|l|l|}
\hline & EC4 & 0.758 & & & \\
\hline & EC5 & 0.653 & & & \\
\hline & EC6 & 0.691 & & & \\
\hline & EC7 & 0.773 & & & \\
\hline & EC8 & 0.682 & & & \\
\hline & TP1 & 0.771 & 0.652 & 0.929 & 0.912 \\
\hline & TP2 & 0.832 & & & \\
\hline & TP3 & 0.837 & & & \\
\hline & TP4 & 0.767 & & & \\
\hline & TP5 & 0.845 & & & \\
\hline & TP6 & 0.759 & & & \\
\hline & TP7 & 0.835 & & & \\
\hline
\end{tabular}

Discriminant validity measures the degree to which a construct is distinct from another construct in the model (Hair Jr et al., 2017). This articles will use HTMT to assess discriminant validity (Fornell \& Larcker, 1981). The HTMT is defined as the mean value of the item correlations across constructs relative to the mean of the average correlations for the items measuring the same construct. The HTMT approach is an estimate of what the true correlation between two constructs would be, if they were perfectly measured. Discriminant validity problems are present when HTMT values are high (Hair Jr et al., 2017). According to Kline (2015), HTMT value must less than 0.85. However, the latest research by Franke \& Sarstedt (2019) proposed that the value must between 0.85 or 0.90 .

TABLE 2: Results for HTMT value

\begin{tabular}{|l|c|c|c|c|c|}
\hline & $\begin{array}{c}\text { Compensation } \\
\text { and Benefits }\end{array}$ & $\begin{array}{c}\text { External } \\
\text { NB }\end{array}$ & $\begin{array}{c}\text { Internal } \\
\text { NB }\end{array}$ & $\begin{array}{c}\text { Job } \\
\text { Performance }\end{array}$ & $\begin{array}{c}\text { Recruitment \& } \\
\text { Selection }\end{array}$ \\
\hline $\begin{array}{l}\text { Compensation } \\
\text { and Benefits }\end{array}$ & 0.292 & & & & \\
\hline External NB & 0.275 & 0.731 & & & \\
\hline Internal NB & 0.270 & 0.329 & 0.414 & & \\
\hline $\begin{array}{l}\text { Job } \\
\text { Performance }\end{array}$ & 0.295 & 0.270 & 0.393 & 0.545 & \\
\hline $\begin{array}{l}\text { Recruitment } \\
\text { \& Selection }\end{array}$ & & & & \\
\hline
\end{tabular}

In the second stage of analysis, the latent variable score for the first order construct is obtained from smartPLS analysis report and a new model is formed using latent variable score as formative indicators for second order constructs in the model. The assessment of formative constructs will include Variance Inflation Factor (VIF) for multicollinearity evaluation, outer weights for significance checking, and outer loadings for absolute contribution. 
INTERNATIONAL JOURNAL OF ACADEMIC RESEARCH IN BUSINESS AND SOCIAL SCIENCES

Vol. 10, No. 7, July, 2020, E-ISSN: 2222-6990 @ 2020 HRMARS

TABLE 3: Evaluation of Second-order Constructs

\begin{tabular}{|c|c|c|c|c|c|c|}
\hline $\begin{array}{c}\text { Formative } \\
\text { Constructs }\end{array}$ & Indicator & VIF & $\begin{array}{c}\text { Outer } \\
\text { Weights }\end{array}$ & t value & $\begin{array}{c}\text { Outer } \\
\text { loadings }\end{array}$ & t value \\
\hline \multirow{2}{*}{$\begin{array}{c}\text { Networking } \\
\text { Behavior }\end{array}$} & $\begin{array}{c}\text { External } \\
\text { Contact }\end{array}$ & 1.736 & 0.466 & 2.569 & 0.878 & 11.013 \\
\cline { 2 - 7 } & $\begin{array}{c}\text { Internal } \\
\text { Contact }\end{array}$ & 1.736 & 0.632 & 3.648 & 0.935 & 17.65 \\
\hline
\end{tabular}

Multicollinearity is a measure of the extent to which indicators are correlated with each other; however formative indicators are not expected to have correlation among them. Collinearity is measured through Variance Inflated Factor (VIF); high VIF value indicates that collinearity problem among formative indicators. Hair Jr et al., (2017) suggested that acceptable VIF value should be less than 5. The results in Table 3 showed that VIF value are all less than 5. So, there is no issue of multicollinearity among second order formative constructs in this model.

Outer weights of formative indicators are assessed for significance of relative contribution. The recommended value for outer weight is greater than 0.1 (Lohmöller, 2013). If any indicator has significant outer weight, it is further checked for absolute contribution based on outer loadings of indicators (Hair Jr et al., 2016). The bootstrapping procedure using 5000 resamples was applied to identify significance of weights of formative indicators. The results for the outer weights in Table 3 showed that all formative indicators are significant.

Outer loadings are assessed for significance of absolute contribution. Indicators with outer loadings above 0.50 are considered acceptable for formative measurement model. As shown in Table 3, all formative indicators have outer loadings above 0.5 and its $t$-value is also significant, as t-value is above 1.96 at $5 \%$ significance level.

The evaluation of structural model provides assessment for predictive capability of model and relationship among constructs. Evaluation criteria for structural model includes collinearity test, significance of path coefficients, level of determination $\left(R^{2}\right)$ and effect size $\left(f^{2}\right)$.

Like the assessment of formative constructs, all the constructs in structural model are first checked for multicollinearity by assessing VIF value. Hair Jr et al., (2016) recommended that the acceptable value for VIF should be less than 5 . The results in the Table 4 showed that VIF value for all predictor constructs is below 5 and possibility of multicollinearity among constructs is ruled out for the structural model in this study. 
INTERNATIONAL JOURNAL OF ACADEMIC RESEARCH IN BUSINESS AND SOCIAL SCIENCES Vol. 10, No. 7, July, 2020, E-ISSN: 2222-6990 @ 2020 HRMARS

TABLE 4: Assessment of Multicollinearity

\begin{tabular}{|l|c|c|c|c|c|c|}
\hline & $\begin{array}{c}\text { Compensation } \\
\text { \& Benefits }\end{array}$ & $\begin{array}{c}\text { External } \\
\text { Contact }\end{array}$ & $\begin{array}{c}\text { Internal } \\
\text { Contact }\end{array}$ & $\begin{array}{c}\text { Job } \\
\text { Performance }\end{array}$ & $\begin{array}{c}\text { Networking } \\
\text { Behavior }\end{array}$ & $\begin{array}{c}\text { Recruitment } \\
\text { \& Selection }\end{array}$ \\
\hline $\begin{array}{l}\text { Compensation } \\
\text { Benefits }\end{array}$ & & & & 1.199 & 1.497 & \\
\hline $\begin{array}{l}\text { External } \\
\text { Contact }\end{array}$ & & & & & 1.791 & \\
\hline $\begin{array}{l}\text { Internal } \\
\text { Contact }\end{array}$ & & & & & 1.758 & \\
\hline $\begin{array}{l}\text { Job } \\
\text { Performance }\end{array}$ & & & & & & \\
\hline $\begin{array}{l}\text { Networking } \\
\text { Behaviour }\end{array}$ & & & & 1.286 & & \\
\hline $\begin{array}{l}\text { Recruitment \& } \\
\text { Selection }\end{array}$ & & & & 1.542 & 1.571 & \\
\hline
\end{tabular}

By running PLS-SEM algorithm, path coefficients for structural model relationships are obtained. Significance of path coefficients is determined through application of bootstrapping procedure (Hair Jr et al., 2016). Using bootstrapping for 5000 resamples with $5 \%$ significance level, Table 5 shows the results for $t$ value, $p$ value and $95 \%$ confidence interval for the hypothesized relationship among constructs in the structural model. At 5\% significance level, significant t value should be above 1.96 and significant $p$ value should be below 0.05. According to Hair Jr et al., 2016) reporting confidence interval $(\mathrm{Cl})$ along with $\mathrm{t}$ values and $\mathrm{p}$ values provides additional information about significance testing. The confidence interval for specified path coefficient is said to be significant if it does not include value 0 within lower and upper limits of interval (Hair Jr et al., 2016)

With regards to the relation between human resource management practices and employee performance, recruitment and selection, and training and developments have significant relationship on employee performance. Compensation and benefits, and performance appraisals have no significant influence on employee performance. The relation between human resource management practices and networking behavior also produce only two significant relationships which are training and development, and performance appraisals towards networking behavior. Networking behavior shows significant relationship towards employee performance. 
INTERNATIONAL JOURNAL OF ACADEMIC RESEARCH IN BUSINESS AND SOCIAL SCIENCES Vol. 10, No. 7, July, 2020, E-ISSN: 2222-6990 @ 2020 HRMARS

TABLE 5: Assessment of Significance and Relevance Relationship

\begin{tabular}{|c|c|c|c|c|c|c|c|c|c|}
\hline Hypothesis & Relationship & $\begin{array}{l}\text { Std } \\
\text { Beta }\end{array}$ & $\begin{array}{l}\text { Standar } \\
\text { d Error }\end{array}$ & $\begin{array}{l}\text { t- } \\
\text { value }\end{array}$ & $\begin{array}{l}p- \\
\text { value }\end{array}$ & $\begin{array}{l}\mathrm{BCl} \\
\mathrm{LL}\end{array}$ & $\begin{array}{l}\mathrm{BCl} \\
\mathrm{UL}\end{array}$ & $f^{2}$ & $\begin{array}{l}\text { Significanc } \\
\mathrm{e}\end{array}$ \\
\hline $\mathrm{H} 1$ & $\begin{array}{l}\text { Recruitment } \\
\text { \& Selection } \\
\text {-> Job } \\
\text { Performanc } \\
\text { e }\end{array}$ & $\begin{array}{l}0.25 \\
9\end{array}$ & 0.074 & $\begin{array}{l}3.36 \\
0\end{array}$ & $\begin{array}{l}0.00 \\
1\end{array}$ & $\begin{array}{l}0.13 \\
7\end{array}$ & $\begin{array}{l}0.38 \\
0\end{array}$ & $\begin{array}{l}0.054 \\
5\end{array}$ & Yes \\
\hline $\mathrm{H} 2$ & $\begin{array}{l}\text { Compensati } \\
\text { on \& } \\
\text { Benefits -> } \\
\text { Job } \\
\text { Performanc } \\
\text { e }\end{array}$ & $\begin{array}{l}0.03 \\
0\end{array}$ & 0.072 & $\begin{array}{l}0.43 \\
8\end{array}$ & $\begin{array}{l}0.66 \\
1\end{array}$ & $\begin{array}{l}- \\
0.08 \\
8\end{array}$ & $\begin{array}{l}0.14 \\
4\end{array}$ & $\begin{array}{l}0.001 \\
5\end{array}$ & No \\
\hline H3 & $\begin{array}{l}\text { Networking } \\
\text { Behaviour - } \\
>\text { Job } \\
\text { Performanc } \\
\text { e }\end{array}$ & $\begin{array}{l}0.14 \\
1\end{array}$ & 0.066 & $\begin{array}{l}2.18 \\
8\end{array}$ & $\begin{array}{l}0.02 \\
9\end{array}$ & $\begin{array}{l}0.03 \\
6\end{array}$ & $\begin{array}{l}0.24 \\
9\end{array}$ & & Yes \\
\hline
\end{tabular}

$\mathrm{R}^{2}$ determines model predictive accuracy by examining the variance explained in endogenous variable by exogenous variable (Hair Jr et al., 2016). According to Cohen (1988), $R^{2}$ value of 0.02 are considered weak, 0.13 to 0.26 are considered moderate and above 0.26 are taken as substantial. SmartPLS algorithm function is used in this analysis to calculate $\mathrm{R}^{2}$ values, as given in the table below.

The findings in the table below suggest that HRM practices including recruitment and selection practices, compensation and benefit practices, training and development practices and performance appraisals practices explain $25.3 \%$ of total variation in Networking Behavior construct. Moreover, Networking Behavior also contributed 33.6\% variation in Job Performance. Furthermore, results indicate that $\mathrm{R}^{2}$ values are satisfactory based on cut off values given by Cohen (1988) as predictive accuracy level for both Job Performance and Networking Behavior are substantial in this model.

TABLE 6: Assessment Level of $\mathrm{R}^{2}$

\begin{tabular}{|l|l|l|}
\hline Endogenous Construct & $\mathrm{R}^{2}$ value & Predictive Accuracy Level \\
\hline Job Performance & 0.339 & Substantial \\
\hline Networking Behavior & 0.253 & Moderate \\
\hline
\end{tabular}

TABLE 7: Hypothesis on mediation report analysis result

\begin{tabular}{|c|l|c|c|c|c|}
\hline Hypothesis & \multicolumn{1}{|c|}{ Indirect Relationship } & t-value & BCI LL & BCI UL & Significance \\
\hline H4 & $\begin{array}{l}\text { Recruitment \& Selection -> } \\
\text { Networking Behaviour -> Job } \\
\text { Performance }\end{array}$ & 0.383 & -0.014 & 0.032 & No \\
\hline H5 & $\begin{array}{l}\text { Compensation \& Benefits -> } \\
\text { Networking Behaviour -> Job } \\
\text { Performance }\end{array}$ & 0.025 & -0.015 & 0.018 & No \\
\hline
\end{tabular}


The bootstrapping analysis showed that the indirect effect $\beta=0.00$ was significant with a t-value of 3.000. also, the $95 \%$ Bootstrapping Confidence Interval (Cl) (Preacher \& Hayes, 2008) does not straddle a 0 in between $[\mathrm{LL}=0.00, \mathrm{UL}=0.0]$ indicates that there is a mediation. Thus, we conclude that the mediation effect is statistically significant.

The mediation test will be conducted using bootstrapping technique to calculate the $t$-value and confidence interval for determining the significance of indirect effect. For acceptance or rejection of mediation hypothesis $t$-value should be significance ( $t>1.96$, two-tailed, $p<0.05$ ) and confidence interval should not contain value 'zero' between lower and upper limit (Hair Jr et al., 2016; (Latan \& Noonan, 2017). By using bootstrapping procedure with 500 resamples at $5 \%$ significance level and $95 \%$ confidence interval, the results for mediation relationship shown as below table.

From the results it shown that networking behavior only mediates the relationship between training and development and employee performance $(\mathrm{t}=2.009, \mathrm{LL}=0.016, \mathrm{UL}=0.080)$. Networking behavior did not mediate the relationship between recruitment and selection, and employee performance due to $t$-value is below than 1.96 and $95 \% \mathrm{Cl}$ include zero between $\mathrm{UL}$ and $\mathrm{LL}(\mathrm{t}=0.383, \mathrm{LL}=-0.014$, $\mathrm{UL}=0.032$ ). The same reason happens to networking behavior which did not mediate the relationship between compensation and benefits and employee performance $(t=0.025, L L=-0.015, \mathrm{UL}=0.018)$. Lastly, networking behavior did not mediate the relationship between performance appraisals and employee performance due to $\mathrm{t}$-value is below than 1.96 ( $\mathrm{t}=1.701, \mathrm{LL}=0.006, \mathrm{UL}=0.076)$.

\section{Discussion}

The first research objective of this study has produced mixture outcome. Recruitment and selection practices have significant relationship towards employee performance. The findings can expand further the idea in relation to the present study as proposed by Lin et al., (2020) and Sendawula et al., (2018). We can also conclude that the ability of HRM practices to improve their employee's performance is depending on how the organization conduct their recruitment and selection process as well as how effective the university recruited the best talent for their performance. However, compensation and benefits practices are not significant towards employee performance. In private sector, compensation and employee benefits are one of challenges given to employees especially in education sector (Quinlan, 2004). Furthermore, the findings indicated that the compensation and benefits package offered by the university are not attractive enough to motivate their employee to boost their performance in workplace.

The second research objective of this study which to examine the relationship between networking behaviour and employee performance is successfully achieved. Networking behaviour found to be significant towards employee performance. The culture of networking among employees of the university is proven to give them benefits rather than negative impact on their work performance. Furthermore, the university which has twelve campuses around peninsular Malaysia fostering the networking behaviour among them to discuss on work related issues which enhance their performance.

The last research objective also produced mixture outcome whereby most of the hypothesis are rejected. The mediation impact of networking behaviour on recruitment and selection practices, compensation and benefits practices, and performance appraisals towards employee performance are not significant. However, networking behaviour can only mediate the relationship between training and development practices, and employee performance. The employees who are given skills and training will have better performance when they perceived networking behaviour in their 
INTERNATIONAL JOURNAL OF ACADEMIC RESEARCH IN BUSINESS AND SOCIAL SCIENCES Vol. 10, No. 7, July, 2020, E-ISSN: 2222-6990 @ 2020 HRMARS

working place. For instance, the top management required to deal with external stakeholders such government agencies, private industry as well as non-government organization as part of knowledge sharing and information seeking (Avellaneda, 2016)

Nonetheless, there are several limitations in this paper. First, this study was conducted among top management and non-academic staff without considering academic staff as sample. Academic staff certainly have their role and contribution towards university performance. Future research must include academic staff in investigating their networking behavior towards individual performance. Second, this study was adopted individual self-rating on employee performance. This approach was adopted due to difficulty to get objective measures on employee performance from organization. Future research should consider using objective measure of employee performance from organization database. Lastly, this study was conducted in Asia countries, specifically in Malaysia. It is unclear whether the findings can be generalized for any other countries such in another Asian countries or any other countries in the world. In fact, the findings may be varied from this study. Future research must be conducted at other countries to generalize the findings.

\section{Conclusion}

This study intended to present empirical evidence of the relationship between human resource management practices and employee performance through networking behavior of the employees. The researchers have further examined whether networking behavior of employees were able to act as mediator between human resource management practices and performance of the employees. This study has formed new conceptual model of HRM-employee performance, and new instrument which is valid and reliable. Future empirical research can be conducted to investigate the HRMemployee linkages in different scope like academic staff, or other industries involving employees at low level management hierarchy. This study has also furthered modify the HRM-employee performance model with new variables, networking behavior which is overlooked in the mainstream discussion. The findings will contribute on the best practices in private university on producing the best performance among management employees.

This study has contributed to literature on theoretical, managerial and contextual contribution. From theoretical perspective, this study has contributed to the literature by advancing the knowledge in HRM and employees networking behaviour that emerged as contemporary global concern, especially toward Industrial Revolution 4.0. From managerial perspective, this study offers significant insight to employee' policy makers in higher education institutions. They should encourage networking activities among employees and employed the best practices of HRM to their respective employees to gain their performance objective. At the same time, strategic training and development practices could be implied in the university in order to develop their employees networking order which later enhancing their work outcome. From contextual perspective, this study offers new perspective in the management of private university in Malaysia. Employers may focus on the recruitment and selection practices as good application of such practices may affect employee performance for instance individual commitment and work success (Pahos \& Galanaki, 2019). At the same time, networking behavior among management staff in private universities should be encouraged and formalized as it will boost their employee performance at work. 
INTERNATIONAL JOURNAL OF ACADEMIC RESEARCH IN BUSINESS AND SOCIAL SCIENCES Vol. 10, No. 7, July, 2020, E-ISSN: 2222-6990 @ 2020 HRMARS

\section{References}

Aboyassin, N. A., \& Sultan, M. A. F. (2017). The Role of Human Resources Training in Improving the Employee's Performance: Applied Study in the Five Stars Hotels in Jordan. International Journal of Business Administration, 8(5), 46. https://doi.org/10.5430/ijba.v8n5p46

Albrecht, S. L., Bakker, A. B., Gruman, J. A., Macey, W. H., \& Saks, A. M. (2015). Journal of Organizational Effectiveness: People and Performance. Journal of Organizational Effectiveness: People and Performance, 2(1), 7-35. https://doi.org/10.1108/JOEPP-09-2015-0031

Amaratunga, D., Baldry, D., Sarshar, M., \& Newton, R. (2002). Quantitative and qualitative research in the built environment: application of "mixed" research approach. Work Study, 51(1), 17-31. https://doi.org/10.1108/00438020210415488

Amin, M., Ismail, K. W. W., Abdul Rasid, Z. S., \& Selemani, D. A. R. (2014). The impact of human resource management practices on performance. The TQM Journal, 26(2), 125-142. https://doi.org/10.1108/TQM-10-2011-0062

Armstrong, M. (2006). A handbook of human resource management practice. Kogan Page Publishers.

Avellaneda, C. N. (2016). Government Performance and Chief Executives' Intangible Assets: Motives, Networking, and/or Capacity? Public Management Review, 18(6), 918-947. https://doi.org/10.1080/14719037.2015.1051574

Baba, A. J., \& David, N. (2020). Do high-performance work systems mediate the relationship between HR practices and employee performance in multinational corporations (MNCs) in developing economies? African Journal of Economic and Management Studies. https://doi.org/10.1108/AJEMS-01-2019-0028

Bagozzi, R. P., \& Yi, Y. (1988). On the evaluation of structural equation models. Journal of the Academy of Marketing Science, 16(1), 74-94. https://doi.org/10.1007/BF02723327

Basu, G., Jeyasingam, J., Habib, M., Letchmana, U., \& Ravindran, R. (2017). The Impact of Supply Chain Management Practices on the Performance of Private Universities in Malaysia. International Journal of Supply Chain Management, 6(3), 22-35.

Chang, P. C., \& Chen, S. J. (2011). Crossing the level of employee's performance: HPWS, affective commitment, human capital, and employee job performance in professional service organizations. International Journal of Human Resource Management, 22(4), 883-901. https://doi.org/10.1080/09585192.2011.555130

Chin, W. W. (1997). Overview of the PLS Method. University of Houston.

Cohen, J. (1988). Statistical power analysis for the social sciences.

Fornell, C., \& Larcker, D. F. (1981). Structural Equation Models with Unobservable Variables and Measurement Error: Algebra and Statistics. Journal of Marketing Research, 18(3), 382. https://doi.org/10.2307/3150980

Forret, M. L., \& Dougherty, T. W. (2001). Correlates of Networking Behavior for Managerial and Professional Employees. Group \& Organization Management, 26(3), 283-311. https://doi.org/10.1177/1059601101263004

Forret, M. L., \& Dougherty, T. W. (2004). Networking Behaviors and Career Outcomes : Differences for Men and Women? Networking behaviors and career outcomes : differences for men and women ? 437(MAY), 419-437. https://doi.org/10.1002/job.253

Franke, G., \& Sarstedt, M. (2019). Heuristics versus statistics in discriminant validity testing: a comparison of four procedures. Internet Research, 29(3), 430-447. 
INTERNATIONAL JOURNAL OF ACADEMIC RESEARCH IN BUSINESS AND SOCIAL SCIENCES

Vol. 10, No. 7, July, 2020, E-ISSN: 2222-6990 @ 2020 HRMARS

https://doi.org/10.1108/IntR-12-2017-0515

Garg, D. N., \& Sharma, B. (2015). The Mediating Role of Employee Engagement in the Relationship between High Performance Work Practices and Job Performance. SSRN Electronic Journal, XXVII(May 2015), 85-102. https://doi.org/10.2139/ssrn.2694991

Ghasemy, M., Hussin, S., Megat Daud, M. A. K., Nor, M., Ghavifekr, S., \& Kenayathulla, H. B. (2018). Issues in Malaysian Higher Education: A Quantitative Representation of the Top Five Priorities, Values, Challenges, and Solutions From the Viewpoints of Academic Leaders. SAGE Open, 8(1). https://doi.org/10.1177/2158244018755839

Gibson, C., Hardy, J. H., \& Buckley, M. R. (2014). Understanding the role of networking in organizations. Career Development International, 19(2), 141-161. https://doi.org/10.1108/CDI09-2013-0111

Gile, P. P. (2013). The Effect of Human Resource Practices on Employee Performance in Hospitals: A Systematic Review. Working Paper of Public Health, 2(1), 19-26. https://doi.org/10.4081/wpph.2013.6756

Hair, Jr. J. F., Hult, G. T. M., Ringle, C., \& Sarstedt, M. (2016). A primer on partial least squares structural equation modeling (PLS-SEM). Sage publications.

Hair, Jr. J. F., Sarstedt, M., Ringle, C. M., \& Gudergan, S. P. (2017). Advanced issues in partial least squares structural equation modeling. Sage Publications.

Hernandez-Espallardo, M., Osorio-Tinoco, F., \& Rodriguez-Orejuela, A. (2018). Improving firm performance through inter-organizational collaborative innovations: The key mediating role of the employee's job-related attitudes. Management Decision. https://doi.org/10.1108/MD-022017-0151

Ikem, C. O. (2019). Training and employee performance of Auto Parts Manufacturing SMEs in Nnewi, Anambra State. EPRA International Journal of Research and Development (IJRD), 4(2).

Imna, M., \& Hassan, Z. (2015). Influence of Human Resource Management Practices on Employee Retention in Maldives Retail Industry. International Journal of Accounting and Business Management, 4(2), 50-80. https://doi.org/10.24924/ijabm/2015.04/v3.iss1/50.80

Jackson, S. E., Schuler, R. S., \& Jiang, K. (2014). An Aspirational Framework for Strategic Human Resource Management. Academy of Management Annals, 8(1), 1-56. https://doi.org/10.1080/19416520.2014.872335

Jiang, K., Lepak, D. P., Han, K., Hong, Y., Kim, A., \& Winkler, A. L. (2012). Clarifying the construct of human resource systems: Relating human resource management to employee performance. Human Resource Management Review, 22(2), 73-85. https://doi.org/10.1016/j.hrmr.2011.11.005

Jiang, K., Takeuchi, R., \& Lepak, D. P. (2013). Where do we go from here? New perspectives on the black box in strategic human resource management research. Journal of Management Studies, 50(8), 1448-1480. https://doi.org/10.1111/joms.12057

Jolaosho, S. O., Shodiya, O. A., Raji, O. A., \& Akintan, I. O. (2018). The effect of recruitment and selection process on job performance in telecommunication industry in Nigeria: An assessment of MTN Customer Service Centre Abeokuta. International Journal of Management and Economics Invention, 4(02), 1639-1651. https://doi.org/10.18535/ijmei/v4i2.03

Juan, A. Marin-Garcia, \& Tomas, J. M. (2016). Deconstructing AMO framework: A systematic review. Intangible Capital, 12(4), 1040-1087. https://doi.org/10.3926/ic.838

Kline, R. B. (2015). Principles and practice of structural equation modeling. Guilford publications. 
INTERNATIONAL JOURNAL OF ACADEMIC RESEARCH IN BUSINESS AND SOCIAL SCIENCES

Vol. 10, No. 7, July, 2020, E-ISSN: 2222-6990 @ 2020 HRMARS

Latan, H., \& Noonan, R. (2017). Partial least squares path modeling: Basic concepts, methodological issues and applications. Partial Least Squares Path Modeling: Basic Concepts, Methodological Issues and Applications, 1-414. https://doi.org/10.1007/978-3-319-64069-3

Lin, C., Wang, C. Y. P., Wang, C. Y., \& Jaw, B. S. (2017). The role of human capital management in organizational competitiveness. Social Behavior and Personality, 45(1), 81-92. https://doi.org/10.2224/sbp.5614

Lin, L. H., Yang, L. J., Training, P., Employee, D. O., At, P., Hotels, S., \& Sarawak, I. (2020). A STUDY OF THE EFFECT OF PERCEIVED TRAINING AND DEVELOPMENT ON EMPLOYEE PERFORMANCE AT. 12-24.

Liu, J., Hui, C., Lee, C., \& Chen, Z. X. (2013). Why do I feel valued and why do I contribute? A relational approach to employee's organization-based self-esteem and job performance. Journal of Management Studies, 50(6), 1018-1040. https://doi.org/10.1111/joms.12037

Lohmoller, J.-B. (2013). Latent variable path modeling with partial least squares. Springer Science \& Business Media.

Loo, L.-H., \& Beh, L.-S. (2015). The marriage between strategic human resource management and firm performance, the journey to everlasting love. Asian Journal of Management Research, 449(2).

Malik, M. (2019). Teks Ucapan Menteri Pendidikan Malaysia. Majlis TVET Empowerment, 2019(September), 1-9. https://doi.org/.1037//0033-2909.126.1.78

Marques-Sanchez, P., Munoz-Doyague, M. F., Martinez, Y. V., Everett, M., Serrano-Fuentes, N., Van Bogaert, P., ... Reeves, D. (2018). The importance of external contacts in job performance: a study in healthcare organizations using social network analysis. International Journal of Environmental Research and Public Health, 15(7). https://doi.org/10.3390/ijerph15071345

Moqbel, M., \& Aftab, F. (2015). Employees' Social Networking Site Use Impact on Job Performance: Evidence from Pakistan. AIS Transactions on Replication Research, 1(December), 1-11. https://doi.org/10.17705/1atrr.00006

Nasir, S. Z. (2017). Emerging Challenges of HRM in 21st Century: A Theoretical Analysis. International Journal of Academic Research in Business and Social Sciences, 7(3), 216-223. https://doi.org/10.6007/IJARBSS/v7-i3/2727

Nesheim, T., Olsen, K. M., \& Sandvik, A. M. (2017). Never walk alone: achieving work performance through networking ability and autonomy. Employee Relations, 39(2), 240-253. https://doi.org/10.1108/ER-09-2016-0185

Nor, N. M., \& Abdullah, F. (2020). The Relationships between Ability, Motivation and Opportunity ( AMO ) Model of High-Performance Work Practices ( HPWP ) and Organizational Performance on Millennials in MARA Headquarters, Kuala Lumpur : Mediated by Job Embeddedness. International Journal of Academic Research in Business and Social Sciences, 10(13), 62-72. https://doi.org/10.6007/IJARBSS/v10-i13/6889

Nunnally, J. C. (1978). Psychometric Theory: 2d Ed. McGraw-Hill.

Orpen, C. (1996). Dependency as a moderator of the effects of networking behavior on managerial career success. Journal of Psychology: Interdisciplinary and Applied, 130(3), 245-248. https://doi.org/10.1080/00223980.1996.9915006

Pahos, N., \& Galanaki, E. (2019). Staffing practices and employee performance: the role of age. Evidence-Based HRM, 7(1), 93-112. https://doi.org/10.1108/EBHRM-01-2018-0007

Porter, C. M., Woo, S. E., \& Campion, M. A. (2016). Internal and External Networking Differentially 
INTERNATIONAL JOURNAL OF ACADEMIC RESEARCH IN BUSINESS AND SOCIAL SCIENCES

Vol. 10, No. 7, July, 2020, E-ISSN: 2222-6990 @ 2020 HRMARS

Predict Turnover Through Job Embeddedness and Job Offers. Personnel Psychology, 69(3), 635-672. https://doi.org/10.1111/peps.12121

Psychology, O., \& Management, T. (2002). Guest2002. 335-358. https://doi.org/10.1111/14729296.00053

Punch, K. F. (2003). Survey research: The basics. Sage.

Quinlan, M. (2004). Workers' compensation and the challenges posed by changing patterns of work: evidence from Australia. Policy and Practice in Health and Safety, 2(1), 25-52. https://doi.org/10.1080/14774003.2004.11667642

Rasdi, R. M., Garavan, T. N., \& Ismail, M. (2013). Networking behaviours and managers' career success in the Malaysian public service: The moderating effect of gender. Personnel Review, 42(6), 684-703. https://doi.org/10.1108/PR-07-2010-0117

Rashid, S., Hamza, M. F. Ben, \& Said, H. M. (2018). Impacts of Rewards, Promotions and Supervisor Support on Academic Staff's Performance: An Empirical Study in Malaysian Universities. International Journal of Academic Research in Business and Social Sciences, 8(9), 1983-1998. https://doi.org/10.6007/ijarbss/v8-i9/4877

Ravi, A. (2019). Knowledge Management Skills and Its Impact on Job Performance of Employees Working in Selected I.T. Companies in Hyderabad. International Journal of Recent Technology and Engineering, 8(4), 3580-3585. https://doi.org/10.35940/ijrte.d7804.118419

Sendawula, K., Kimuli, N. S., Bananuka, J., \& Muganga, N. G. (2018). Training, employee engagement and employee performance: Evidence from Uganda's health sector. Cogent Business and Management, 5(1), 1-12. https://doi.org/10.1080/23311975.2018.1470891

Sharafizad, J. (2012). Determinants of business networking behaviour of women in small businesses. Small Enterprise Research, 18(2), 158-160.

https://doi.org/10.5172/ser.2011.18.2.158

Spurk, D., Kauffeld, S., Barthauer, L., \& Heinemann, N. S. R. (2015). Fostering networking behavior, career planning and optimism, and subjective career success: An intervention study. Journal of Vocational Behavior, 87, 134-144. https://doi.org/10.1016/j.jvb.2014.12.007

Subramony, M., Segers, J., Chadwick, C., \& Shyamsunder, A. (2018). Leadership development practice bundles and organizational performance: The mediating role of human capital and social capital. Journal of Business Research, 83(December 2016), 120-129. https://doi.org/10.1016/j.jbusres.2017.09.044

Tauhed, S. Z., Mohd. Rasdi, R., Ibrahim, R., \& Abu Samah, B. (2019). The Influence of Networking, Individual Effort, and Time Management on Research Performance of Academics at Malaysian Research Universities. Revista Publicando, (19). https://doi.org/.1037//0033-2909.126.1.78

Williams, L. J., \& Anderson, S. E. (1991). Job Statisfiction and Organizational Commitment as PRedictors of Organizational Citizenship and In-Role Behaviors. Journal of Management, Vol. 17, pp. 601-617.

Wolff, H. G., Schneider-Rahm, C. I., \& Forret, M. L. (2011). Adaptation of a German multidimensional networking scale into english. European Journal of Psychological Assessment, 27(4), 244-250. https://doi.org/10.1027/1015-5759/a000070

Wright, P. M., Dunford, B. B., \& Snell, S. A. (2001). Human resources and the resource based view of the firm. Journal of Management, 27(6), 701-721.

https://doi.org/10.1177/014920630102700607

Wu, W., Liu, J., \& Shang, X. (2018). Gain without pay causes lazybones' loss: The influence of formal 
INTERNATIONAL JOURNAL OF ACADEMIC RESEARCH IN BUSINESS AND SOCIAL SCIENCES

Vol. 10, No. 7, July, 2020, E-ISSN: 2222-6990 @ 2020 HRMARS

and informal leader-member relationships on customer service performance. Chinese Management Studies, 12(3), 634-657. https://doi.org/10.1108/CMS-03-2017-0057

McCallum, Y. S., Forret, L. M., \& Wolff, H.-G. (2014). Internal and external networking behavior. Career Development International, 19(5), 595-614. https://doi.org/10.1108/CDI-08-2013-0101

Yen, Y. S., Chen, M. C., \& Su, C. H. (2020). Social capital affects job performance through social media. Industrial Management and Data Systems, (2017). https://doi.org/10.1108/IMDS-092019-0473 